\title{
The Barkman Site (41BW693) in the Red River Valley in Northeast Texas
}

Timothy K. Perttula

R. Bo Nelson

Tejas Archaeology

Follow this and additional works at: https://scholarworks.sfasu.edu/ita

Part of the American Material Culture Commons, Archaeological Anthropology Commons, Environmental Studies Commons, Other American Studies Commons, Other Arts and Humanities Commons, Other History of Art, Architecture, and Archaeology Commons, and the United States History Commons

Tell us how this article helped you.

This Article is brought to you for free and open access by the Center for Regional Heritage Research at SFA ScholarWorks. It has been accepted for inclusion in Index of Texas Archaeology: Open Access Gray Literature from the Lone Star State by an authorized editor of SFA ScholarWorks. For more information, please contact cdsscholarworks@sfasu.edu. 


\section{The Barkman Site (41BW693) in the Red River Valley in Northeast Texas \\ Creative Commons License \\ (c) $($ ) $(9)$}

This work is licensed under a Creative Commons Attribution-NonCommercial 4.0 International License 


\title{
The Barkman Site (41BW693) in the Red River Valley in Northeast Texas
}

\author{
Timothy K. Perttula and Bo Nelson
}

\section{Introduction and Site Setting}

The Barkman site (41BW693) is an ancestral Caddo settlement on a natural alluvial rise in the Red River floodplain in Bowie County, Texas (Figure 1). The rise is on the north side of Clear Lake, an old river channel and now an oxbow lake, about 140 meters northwest of the large platform mound at the Hatchel site (41BW3, see Perttula 2014, 2015, 2018). The Hatchel site is a major ancestral Caddo village and mound center on a natural levee deposit in the floodplain of the Red River in Bowie County, Texas, just a few kilometers west of the Arkansas state line, and on the south side of Clear Lake. The platform mound and the main part of the associated village overlooks two channel lakes of the river; these likely were part of the channel of the river when the site was occupied by the Caddo. The Hatchel site was occupied by the Caddo from at least A.D. 1040 to the late $17^{\text {th }}$ century, and the Barkman site appears to have been occupied contemporaneously much of the time with this ancestral Caddo village and mound center.

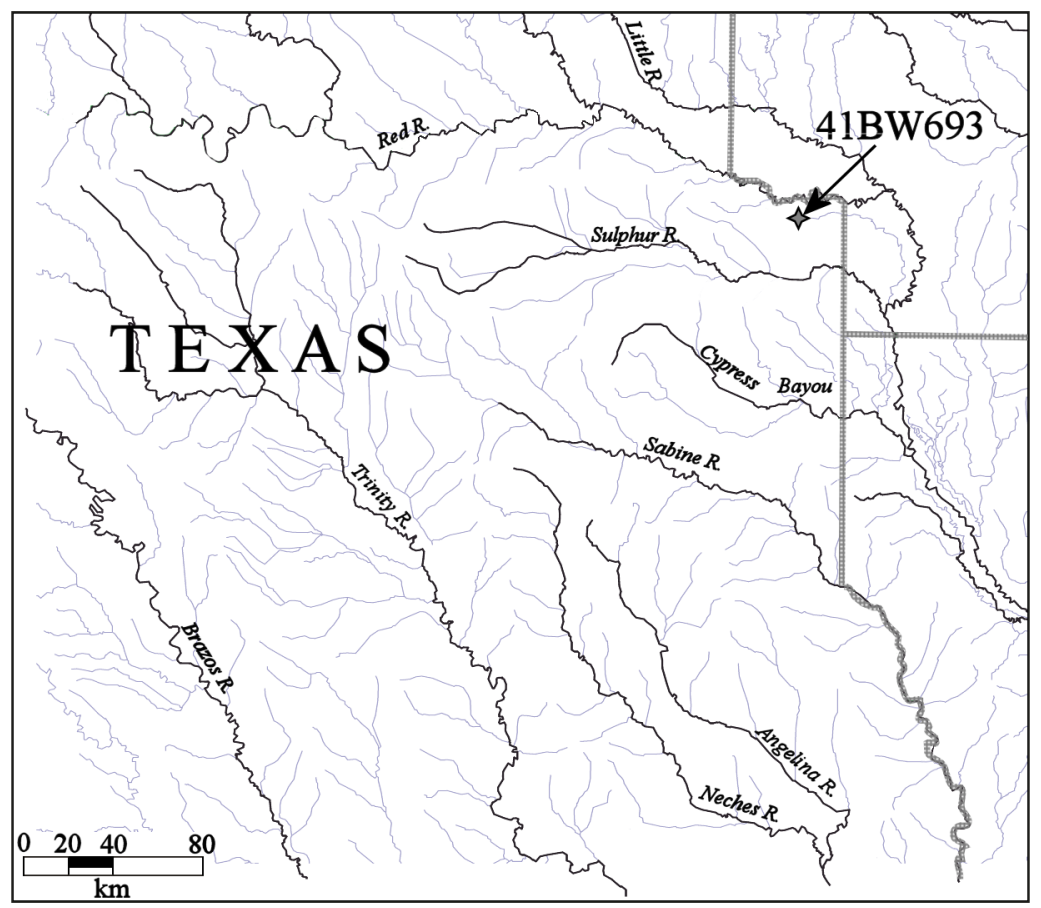

Figure 1. The general location of the Barkman site (41BW693) in Northeast Texas.

The Barkman site covers ca. 10 acres of the alluvial rise, and during the 1970s and 1980s an ancestral Caddo cemetery at the site was subjected to looting activities by several individuals. With the assistance of Julian Cranfill of Texarkana, Texas, who had reconstructed a number of recovered vessels, we were able to photo-document 25 Caddo ceramic vessels from an unknown number of burial features in December 2002, as well as draw decorative motifs of most of the vessels. It is also not known which vessels, if any, of those we have documented are associated with others that we have documented in this article. 


\section{Ancestral Caddo Ceramic Vessels from the Barkman Site}

The 25 ceramic vessels documented from the Barkman site are from both utility ware ( $n=6,24$ percent) and fine ware ( $\mathrm{n}=19,76$ percent) classes. The vessels are uniformly grog-tempered, consistent with ceramic assemblages in this part of the Red River basin (Perttula 2018), except for one Avery Engraved, var. Bradshaw compound bowl, which is shell-tempered and red-slipped; this vessel was likely manufactured by a McCurtain phase potter living in an upstream and middle Red River community (see Regnier et al. 2019), and provided in exchange or trade with ancestral Nasoni Caddo peoples living in what is now modern-day Bowie County, Texas.

\section{Utility Ware}

The utility ware vessels are all jars. They include vessels from the following defined ceramic types (see Suhm and Jelks 1962): Dunkin Incised ( $n=1)$, Haley Complicated-Incised ( $n=2)$, Karnack BrushedIncised $(n=1)$, and Pease Brushed-Incised $(n=2)$. The Dunkin Incised and Haley Complicated jars are from Middle Caddo period contexts (ca. A.D. 1200-1400), while Pease Brushed-Incised vessels are known to occur in both Middle Caddo period and Late Caddo period, early Texarkana phase, burial features (see Perttula 2018:Tables 60 and 61). Karnack Brushed-Incised jars are likely from post-A.D. 1550 Texarkana phase burials at the Barkman site.

The Dunkin Incised jar (No. 54) has single rows of tool punctations below the lip and at the rim-body juncture as well as vertical and diagonal opposed incised lines on the rim and vessel body (Figure 2a). One of the Haley Complicated-Incised jars has prominent rim peaks, with horizontal incised rims and a tool punctated zone on the rim (Figure 3). The body has vertical and diagonal incised lines that separate triangular tool punctated zones. The Karnack Brushed-Incised jar (No. 70) has horizontal brushed marks on the rim and vertical brushed marks on the vessel body. One of the Pease Brushed-Incised jars (No. 46) has single rows of tool punctations beneath the lip and at the rim-body juncture along with diagonal incised lines on the rim and diagonal brushed-incised marks and lines on the vessel body (Figure 2b). The second Pease Brushed-Incised jar (No. 75) from the site has single rows of tool punctations beneath the lip and just below the rim-body juncture, with vertical and diagonal opposed incised panels on the body (Figure 4). These panels are divided by vertical appliqued fillets.
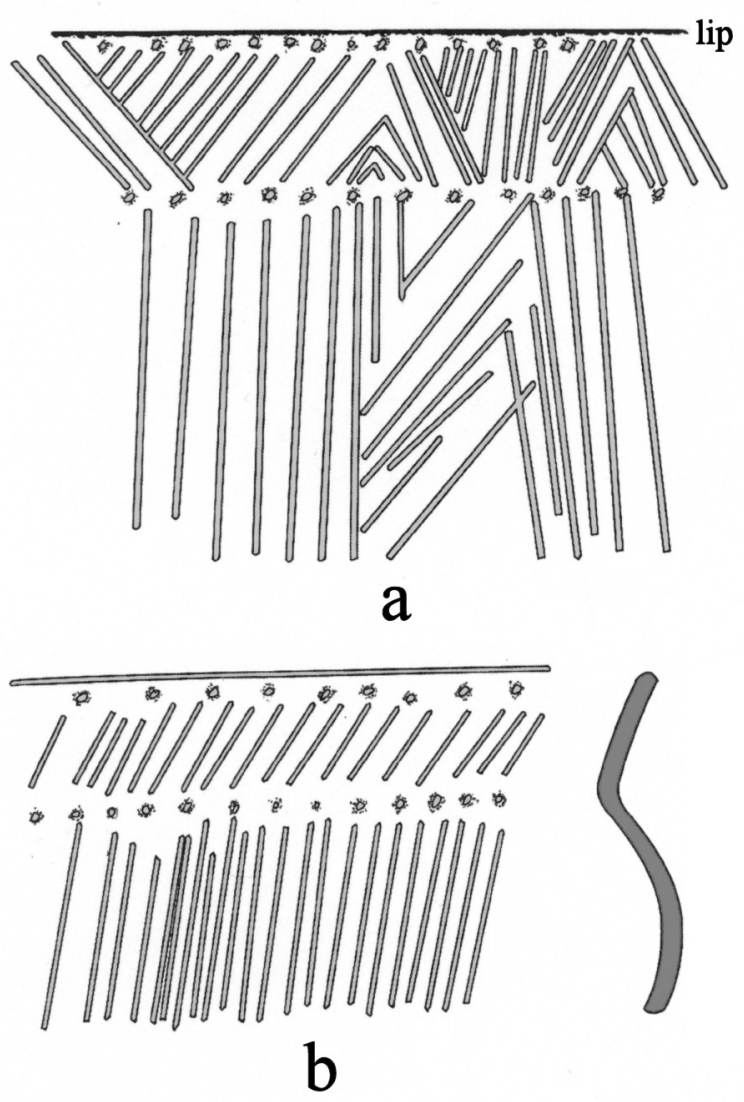

Figure 2. Decorative elements on selected utility ware vessels from the Barkman site: a, Dunkin Incised (No. 54); b, Pease Brushed-Incised (No. 46). 


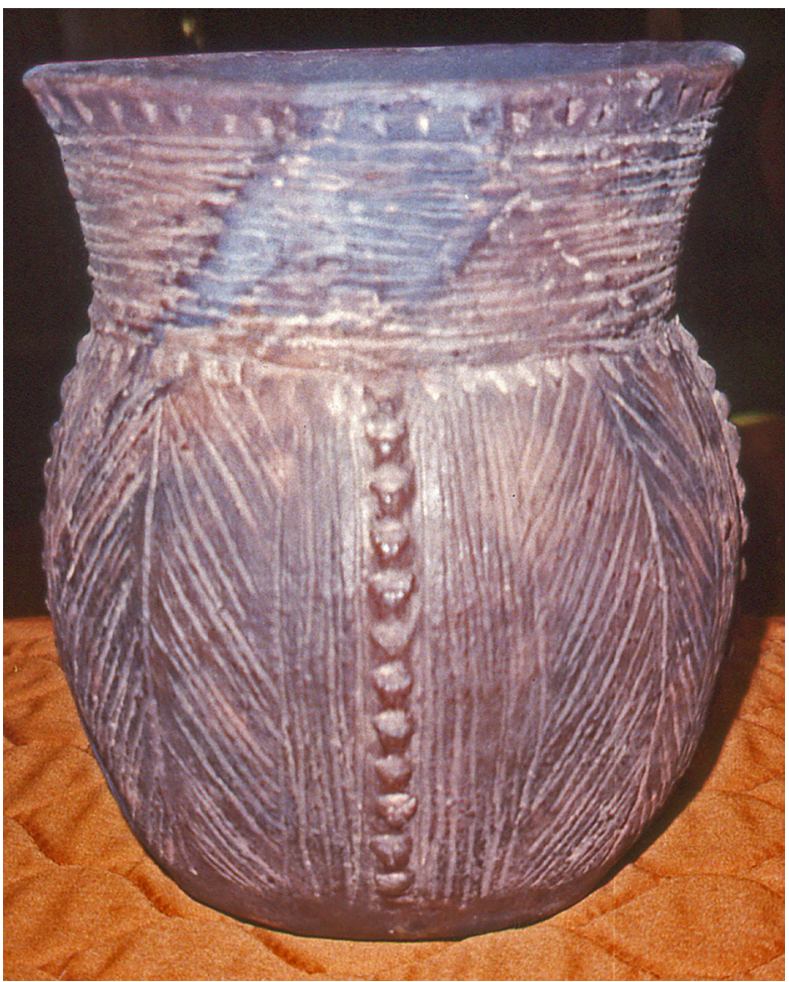

Figure 3. Haley Complicated-Incised jar (No. 57).

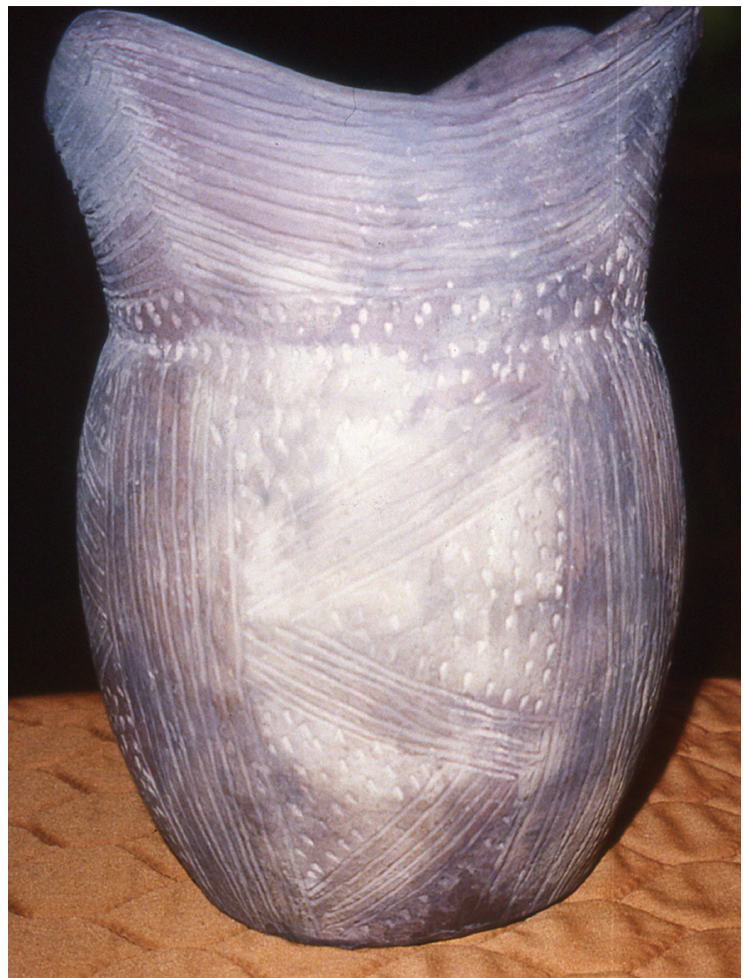

Figure 4. Pease Brushed-Incised jar (No. 75).

\section{Fine Ware}

The fine ware vessels include carinated bowls $(n=14,73.7$ percent $)$, compound bowls $(n=3,15.8$ percent), deep bowls $(n=1,5.3$ percent), and bottles $(n=1,5.3$ percent). These vessels are funerary offerings in ancestral Caddo burial features that apparently date after ca. A.D. 1200, and comprise examples of defined types from Middle Caddo period, Late Caddo period early Texarkana phase, and Late Caddo period late Texarkana phase contexts (see Perttula 2018:Tables 60-62).

The Middle Caddo period, Haley phase, fine ware ceramic vessels from burial features at the Barkman site include a Handy Engraved carinated bowl $(n=1)$ and a Hickory Engraved $(n=1)$ bottle. The Handy Engraved vessel (No. 66) has sets of interlocking scrolls with upper and lower hatched bracket elements as well as surrounding straight scrolls with rounded ends and tick marks (Figure 5). These sets of scrolls are divided by larger hatched bracket elements. The Hickory Engraved bottle (No. 50) has three horizontal engraved lines on the upper body.

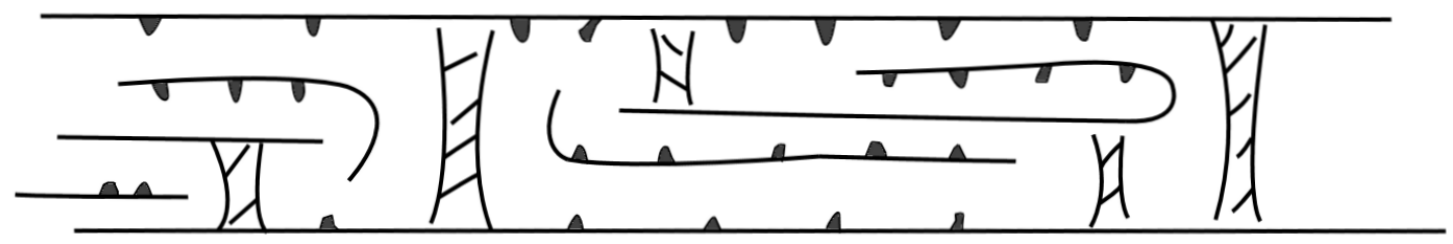

Figure 5. Decorative elements on Handy Engraved carinated bowl (No. 66). 
Bowie Engraved vessels $(n=4)$ are well-represented in both early and late Texarkana phase contexts in this part of the Red River valley (see Perttula 2018:Tables 61-62). The first of the Bowie Engraved vessels is a carinated bowl (No. 58) with horizontal engraved lines above three sets of narrow curvilinear bands with excised tick marks or small punctations (Figure 6d). The second carinated bowl (No. 62) has sets of hatched triangle elements above triangular and curvilinear lines that extend around the rim. Below these lines are either single vertical engraved lines or triangle elements with curvilinear excised zones forming negative ovals (Figure 6c). The third and fourth Bowie Engraved vessels (No. 60 and No. 61) have a series of horizontal engraved lines at the top of the rim as well as hatched pendant triangle elements (see Suhm and Jelks 1962:Plate 9b) (Figures 6a-b, 7, and 8). On Vessel No. 60, the hatched pendant triangles are separated by single vertical engraved lines (Figure 6a).
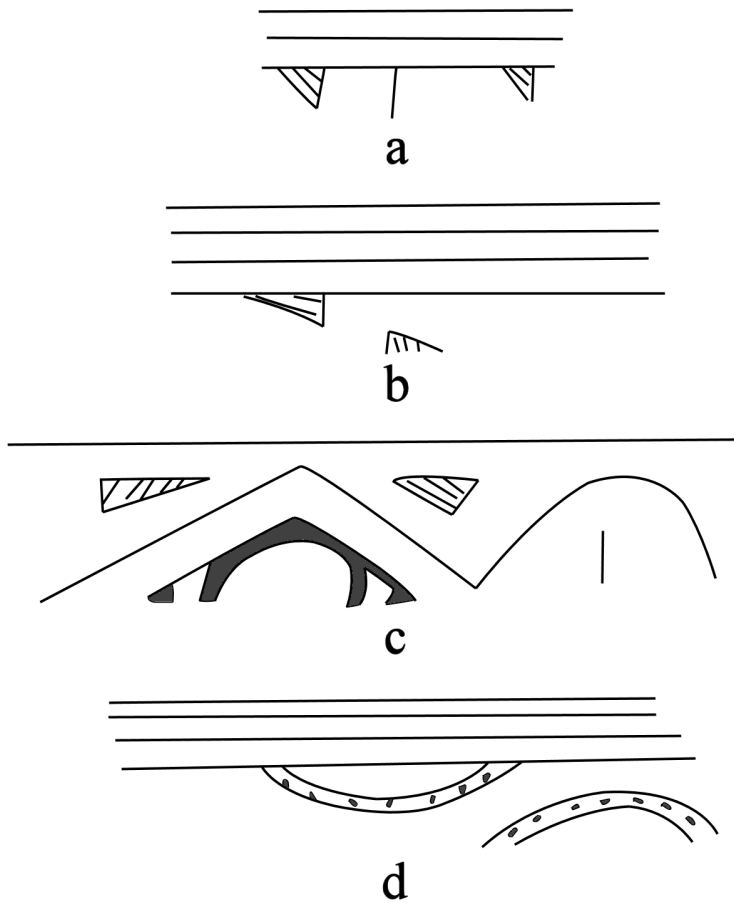

Figure 6. Decorative elements on Bowie Engraved vessels from the Barkman site: a, No. 60; b, No. 61; c, No. 62; d, No. 58 .

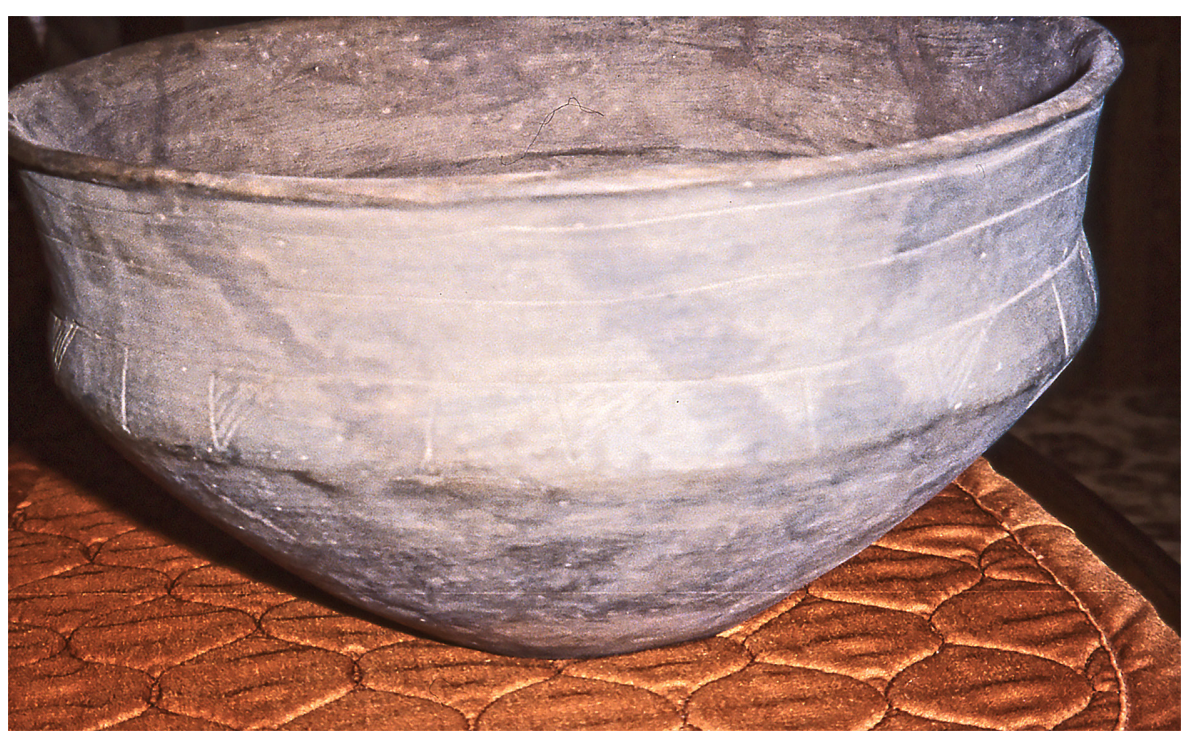

Figure 7. Bowie Engraved compound bowl, No. 60. 


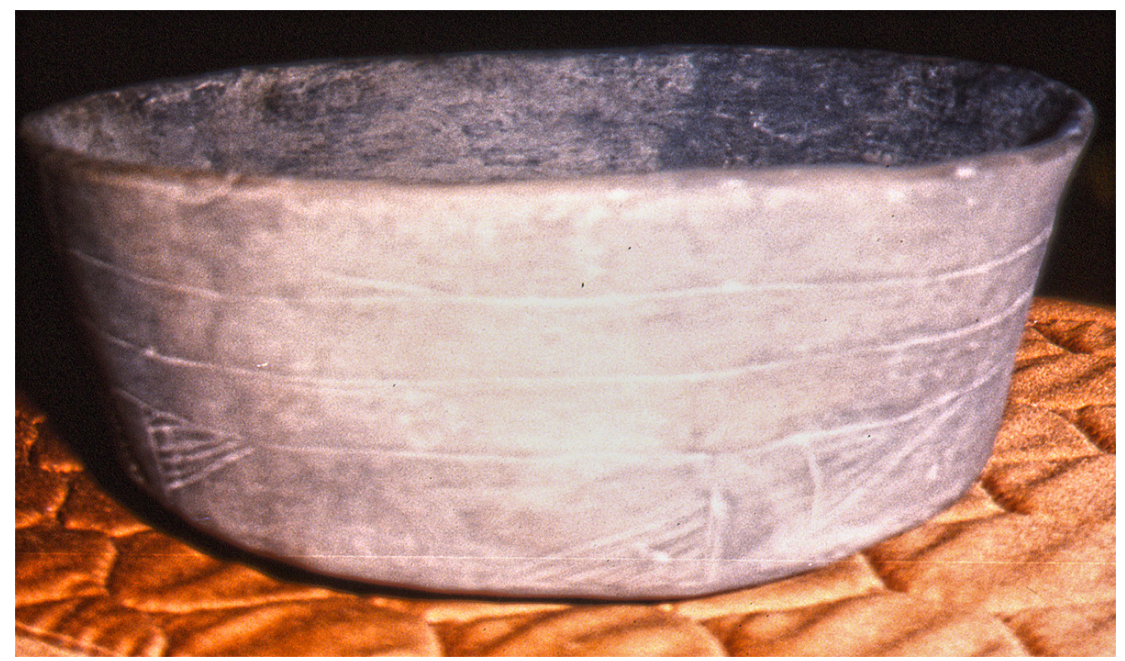

Figure 8. Bowie Engraved bowl, No. 61.

The principal Late Caddo period early Texarkana phase (ca. A.D. 1400-1550) fine ware vessels are Barkman Engraved $(n=6)$ carinated bowls and compound bowls, along with one Avery Engraved, var. Bradshaw compound bowl (see Schambach and Miller 1984:119). The Barkman Engraved vessels feature engraved bands and horizontal or rectilinear scroll elements below a series of horizontal engraved lines at the top of the rim (see Suhm and Jelks 1962:7). The first Barkman Engraved vessel (No. 44) has four horizontal engraved lines above a series of rectilinear scrolls comprised of three closely-spaced lines (Figures 9c and 12). The next vessel (No. 47) has horizontal engraved lines at the top of the rim and a series of upper and lower curvilinear zones filled with excised punctations; these zones are divided by single vertical engraved lines (Figures 9e and 14). A Barkman Engraved deep bowl (No. 53) has curvilinear scrolls divided by hatched brackets and horizontal zones (Figure 9f). A Barkman Engraved compound bowl (No. 75) has similar scroll and bracket elements on its lower rim panel, and the upper rim panel has a single horizontal engraved line mid-panel (Figures 9d and 13). Vessel No. 64, another Barkman Engraved compound bowl, has a plain upper rim panel, and scroll elements divided by excised brackets on the lower rim panel. Above and below the scroll lines are small excised pendant triangle elements (Figures $9 \mathrm{~b}$ and 11). The last Barkman Engraved vessel in the assemblage (No. 63) has horizontal-vertical scroll lines divided by sets of brackets comprised of three nearly vertical curvilinear engraved lines. On either side of the brackets are single hooked arm elements (Figures 9a and 10).

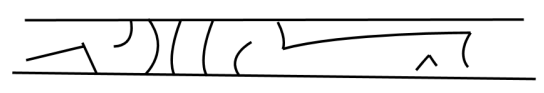

a

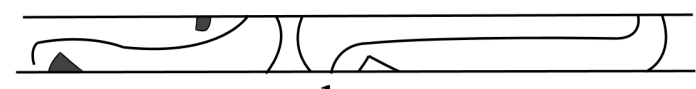

b

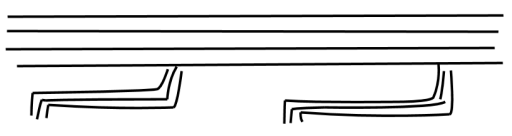

c
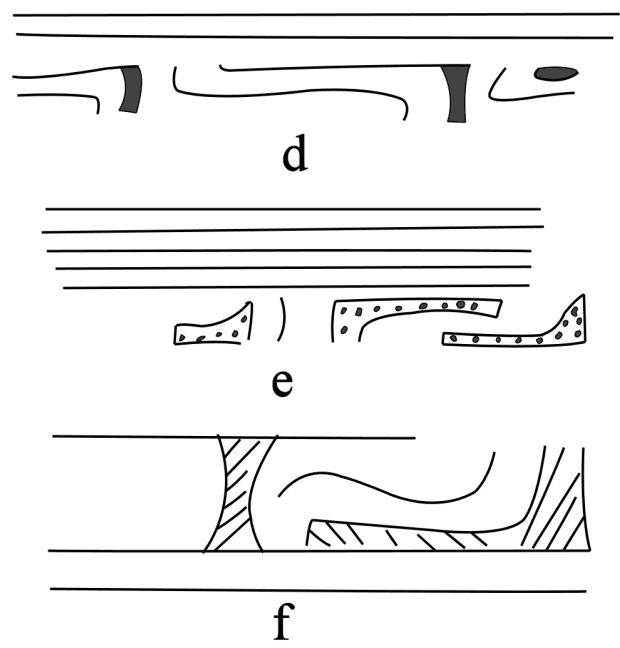

Figure 9. Decorative elements on Barkman Engraved vessels from the Barkman site: a, No. 63; b, No. 64; c, No. 44; d, No. 75; e, No. 47; f, No. 53. 


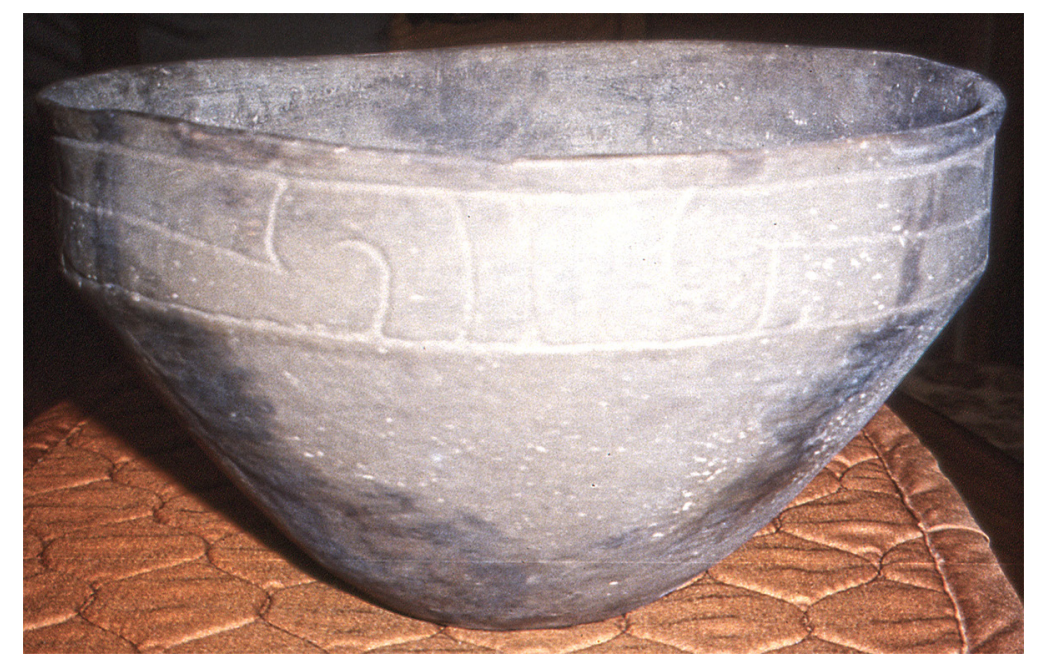

Figure 10. Barkman Engraved carinated bowl, No. 63.

The Avery Engraved, var. Bradshaw compound bowl (No. 59) from the site has a single horizontal engraved line on the upper rim panel. The lower rim panel has large semi-circles with hatched pendant triangles, and the semi-circles are separated across the vessel by large hatched vertical bracket elements (Figures 15a and 16).

The Late Caddo period late Texarkana phase (ca. A.D. 1550-1690) fine ware vessels include Simms Engraved (n=3) and Hodges Engraved, var. Armour (n=1, see Schambach and Miller 1984:Figure 1113a). The first Simms Engraved vessel (No. 71) has a single horizontal engraved line mid-rim, with pendant curvilinear tick marks and small excised pendant triangles (Figures 17a and 18). The second vessel (No. 72), with lip notches, has a mid-rim horizontal engraved line and seven sets of seven closelyspaced vertical engraved lines (Figures 17c and 19). The last Simms Engraved vessel in the collection (No. 76) is a carinated bowl with an inverted rim. On the rim are two horizontal engraved lines with near-vertical tick marks (Figure 17b).

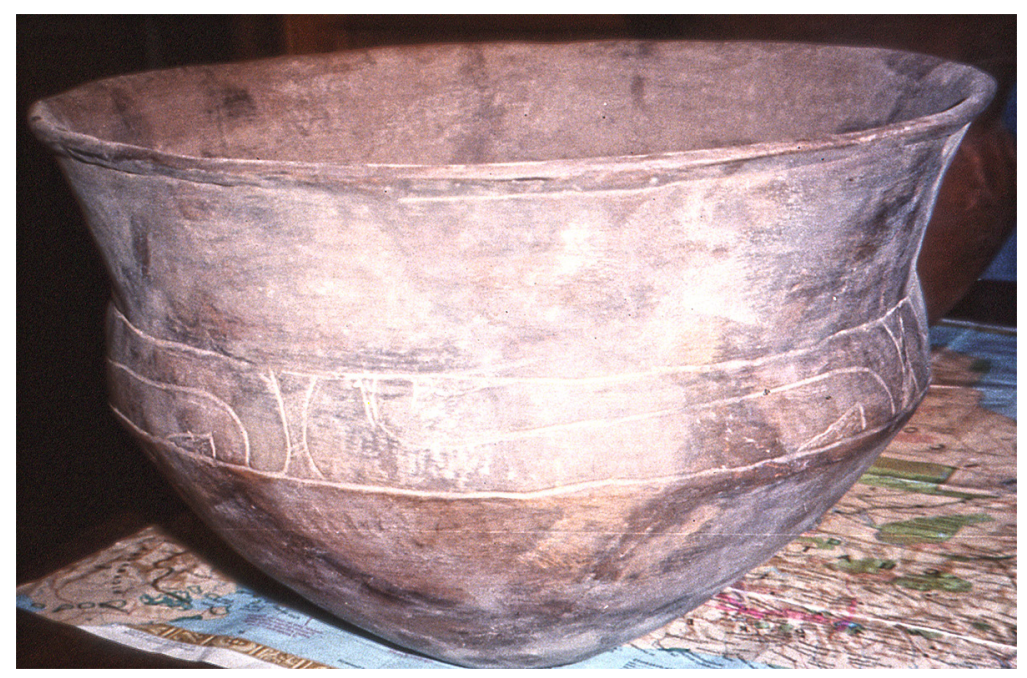

Figure 11. Barkman Engraved compound bowl, No. 64. 


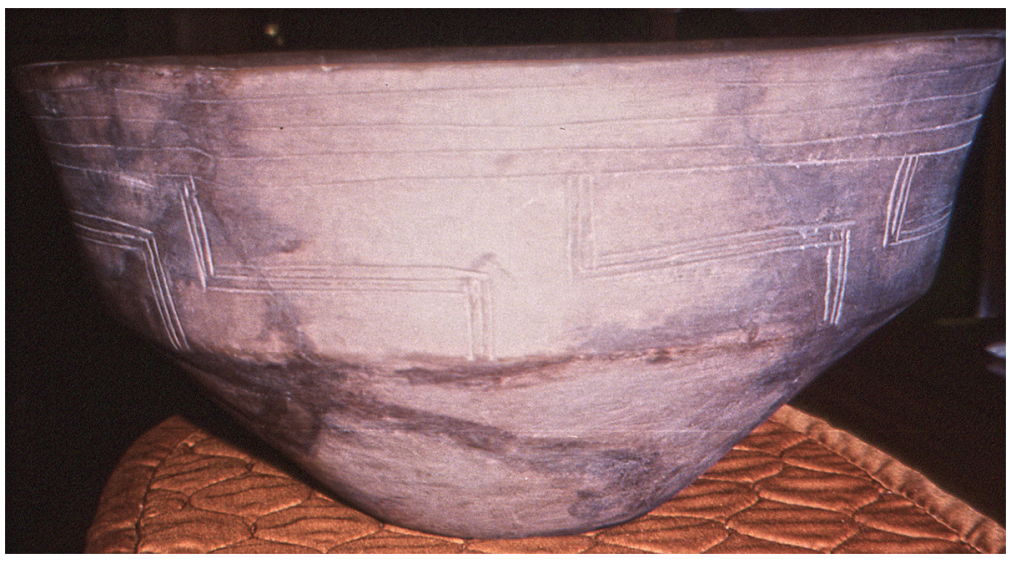

Figure 12. Barkman Engraved carinated bowl, No. 44.

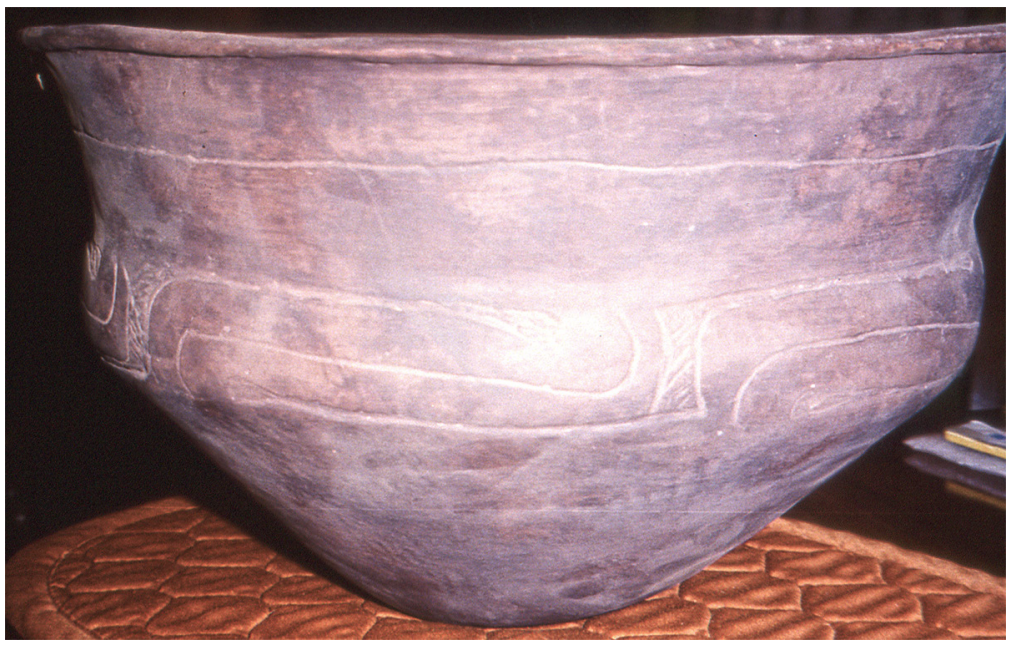

Figure 13. Barkman Engraved compound bowl, No. 75.

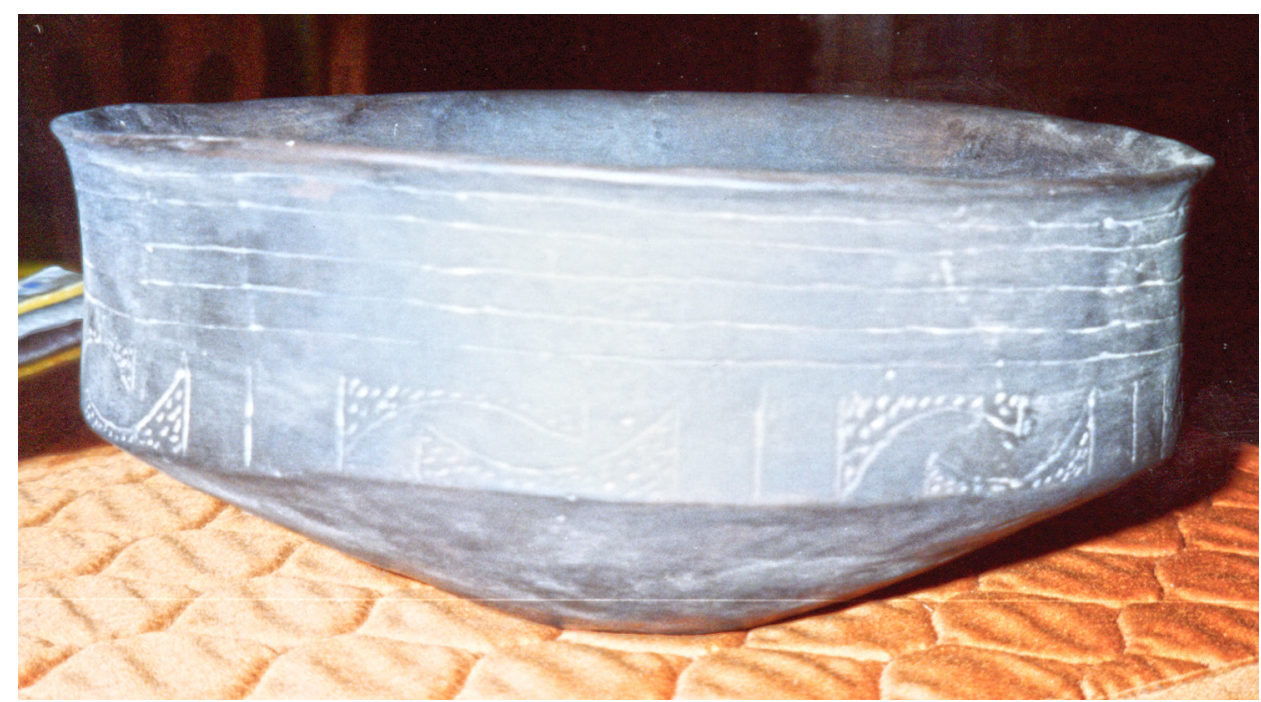

Figure 14. Barkman Engraved carinated bowl, No. 47. 


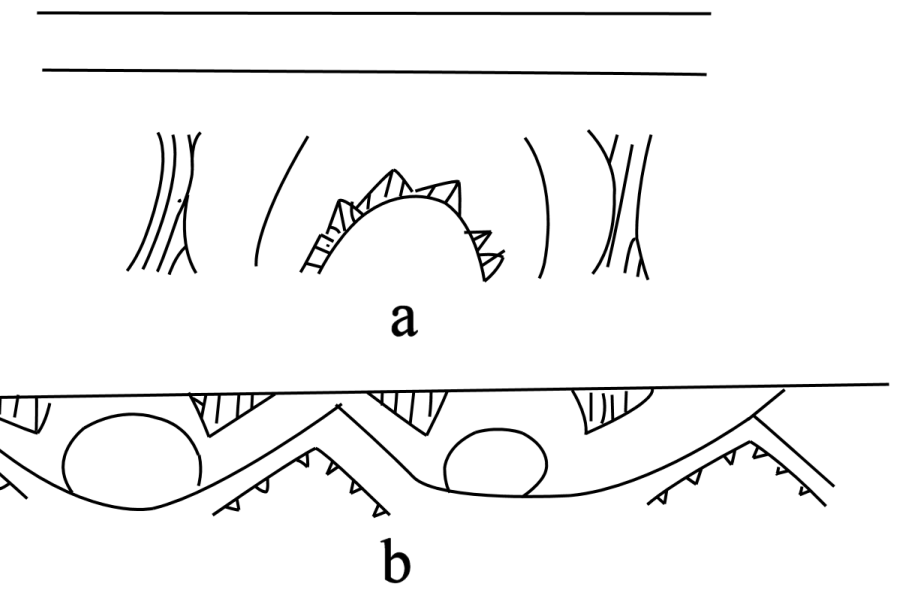

Figure 15. Decorative elements on Avery Engraved and Hodges Engraved vessels from the Barkman site: a, Avery Engraved, var. Bradshaw, No. 59; b, Hodges Engraved, var. Armour, No. 68.

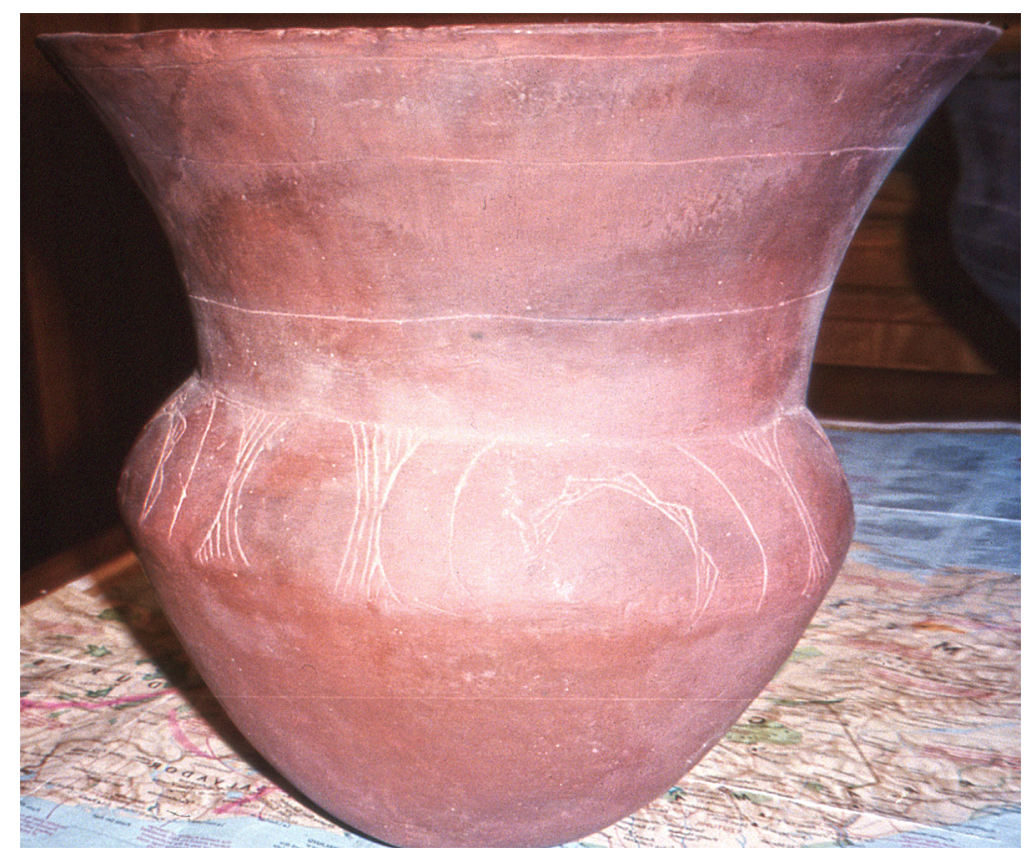

Figure 16. Avery Engraved, var. Bradshaw compound bowl, No. 59.

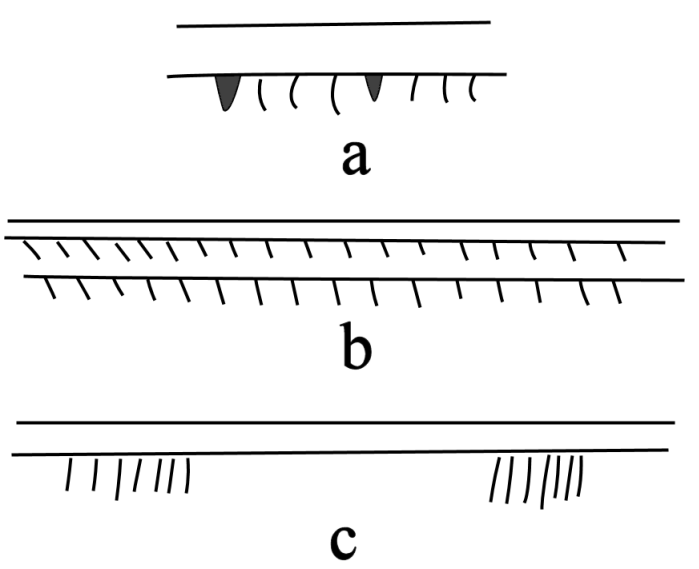

Figure 17. Decorative elements on Simms Engraved vessels from the Barkman site: a, No. 71; b, No. 76; c, No. 72. 


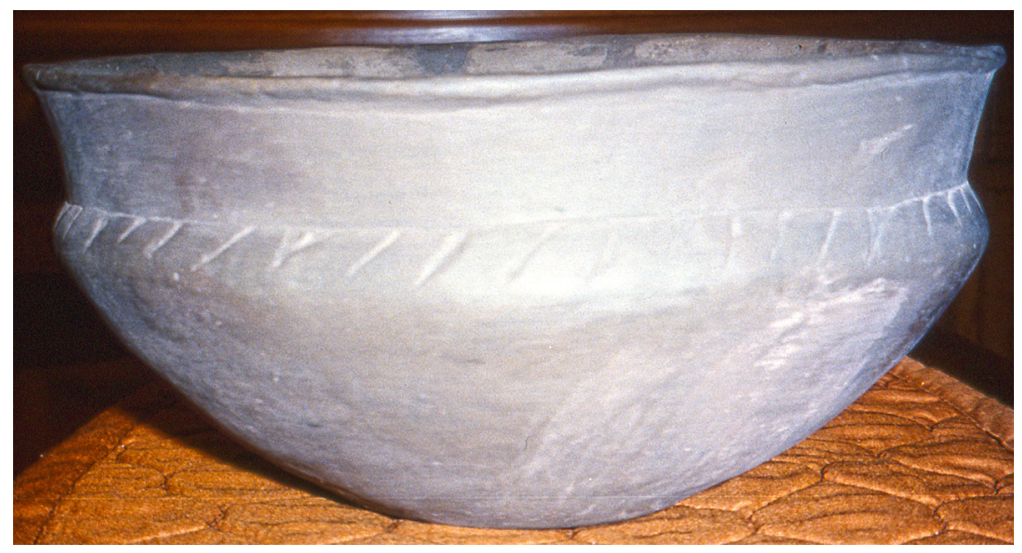

Figure 18. Simms Engraved vessel, No. 71.

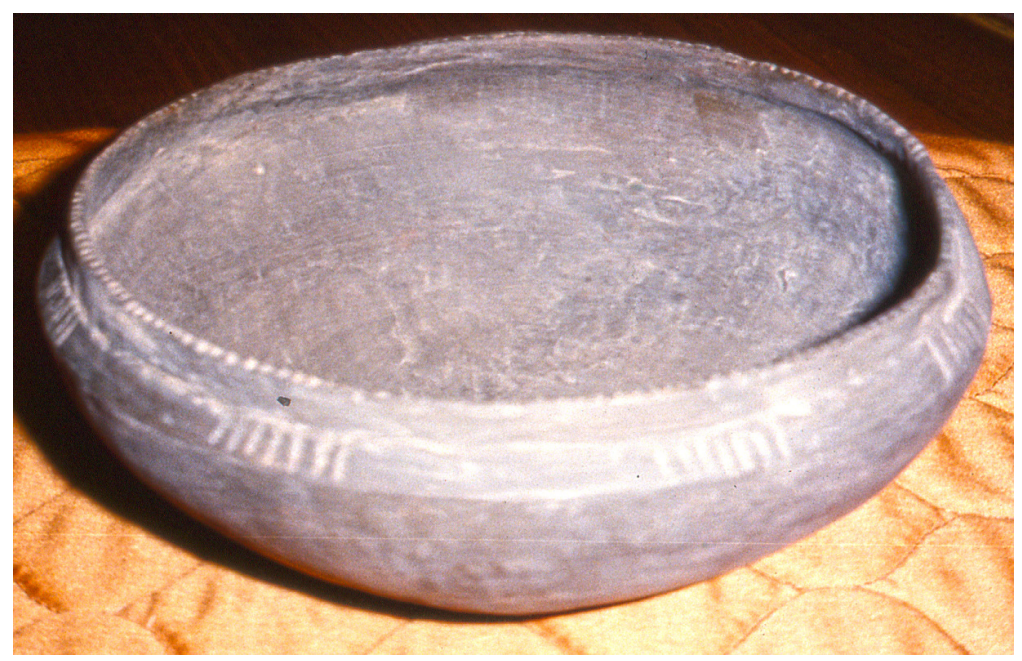

Figure 19. Simms Engraved carinated bowl, No. 72.

The Hodges Engraved, var. Armour carinated bowl (No. 68) in the vessel assemblage has sets of centrally-placed engraved circles connected by slanted scroll lines (see Figure 15b). Below the scroll lines are triangular elements with small open pendant triangles, while above the scroll lines are a series of hatched pendant triangle elements.

Lastly, there are two Ripley Engraved, var. Galt carinated bowls (see Fields 2019:Figure 12-6; Perttula 2019:Figure 9-11c) in the documented vessel assemblage. These are imported vessels made by contemporaneous Titus phase potters that lived in the Big Cypress Creek and Sabine River basins in East Texas; these vessels are likely associated with the early Texarkana phase vessels from the Barkman site vessel assemblage (see Perttula 2019) based on seriations of Ripley Engraved vessels in Titus phase burial features. These Ripley Engraved vessels (No. 48 and No. 65) have central circle elements with inner circle and cross elements, slanted engraved scrolls, and triangular-shaped upper and lower scroll fill zones (Figures 20a-b and 21).

\section{Summary and Conclusions}

The Barkman site (41BW693) is an ancestral Caddo settlement and cemetery in the Red River floodplain, not far north of the Hatchel mound site in Bowie County, Texas. The only archaeological information available about the site came from 2002 personal communications with Julian Cranfill, an avocational archaeologist in the Texarkana area, who knew that the site had been looted in the 1970s and 


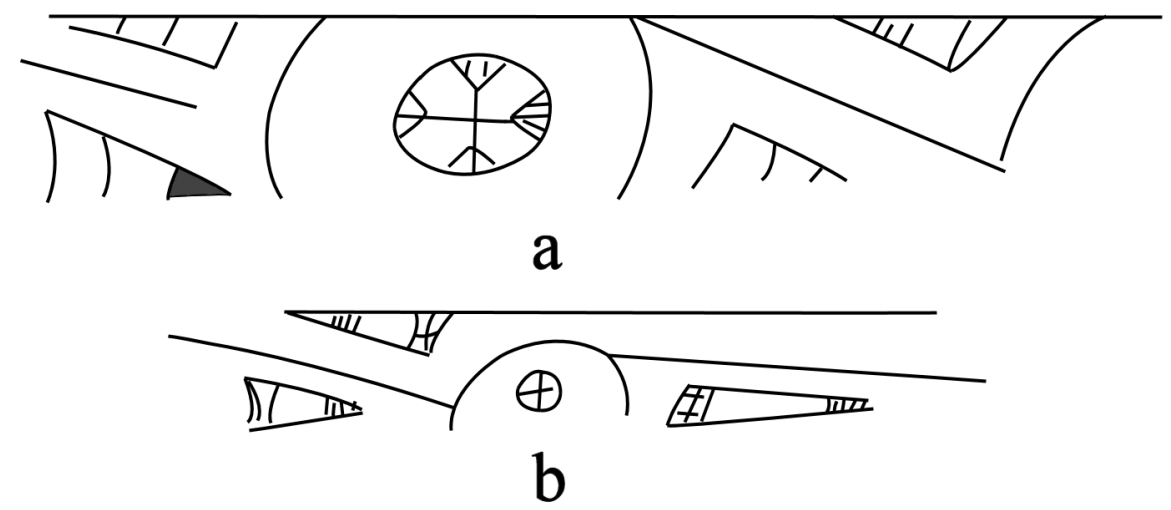

Figure 20. Decorative elements on Ripley Engraved, var. Galt vessels from the Barkman site: a, No. 48; b, No. 65.

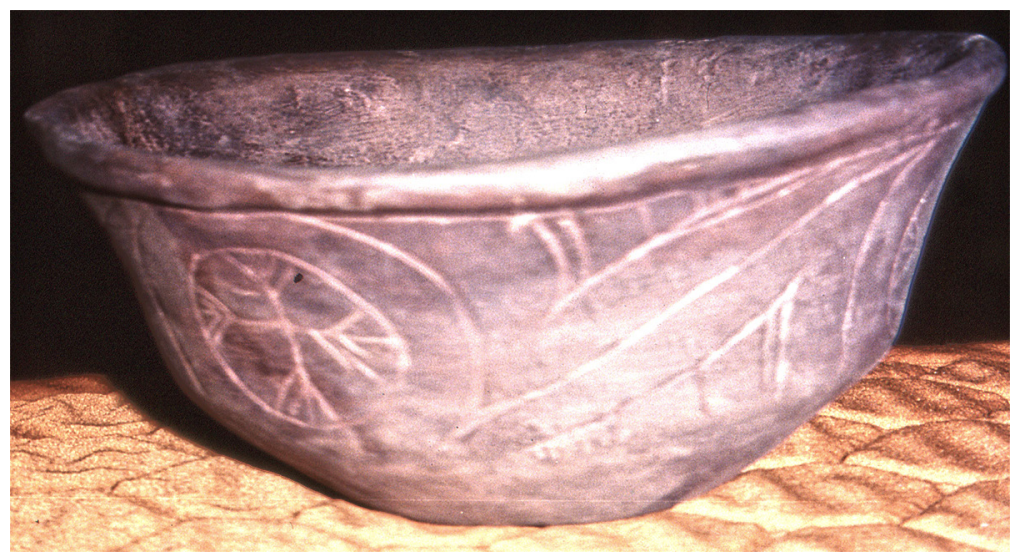

Figure 21. Ripley Engraved, var. Galt carinated bowl, No. 48.

1980s, where an unknown number of Caddo burial features and associated funerary offerings had been uncovered. We were able to document 25 reconstructed ceramic vessels from the site in December 2002, and put this archaeological information on record as part of developing a better understand of ancestral Caddo mortuary practices in the Red River basin in Northeast Texas.

Our documentation of the ceramic vessels, in combination with ceramic typological identifications, from the Barkman site indicates that they are funerary offerings associated with both Middle Caddo period Haley phase (ca. A.D. 1200-1400) and Late Caddo period Texarkana phase (ca. A.D. 1400-1680) burial features that are generally contemporaneous with burial features and vessels at the nearby Hatchel (41BW3) and Mitchell (41BW4) sites. About 20 percent of the vessels are likely from Haley phase contexts, and include Handy Engraved, Haley Complicated-Incised, Hickory Engraved, and Dunkin Incised fine ware and utility wares. The remainder of the vessels from the site represent both early (ca. A.D. 1400-1550) and late (ca. A.D. 1550-1680) Texarkana phase burial features. These include Pease Brushed-Incised and Karnack Brushed-Incised utility ware jars as well as Barkman Engraved, Bowie Engraved, Simms Engraved, Avery Engraved, var. Bradshaw, Hodges Engraved, var. Armour, and Ripley Engraved, var. Galt deep bowls, carinated bowls, and compound bowls.

\section{Acknowledgments}

We thank Julian Cranfill for providing the opportunity to document ceramic vessels from the Barkman site, and for allowing us to obtain photographs of the reconstructed vessel collection. Lance Trask prepared a number of figures for this article, and scans of slides and prints of the vessels were done by Jeff Arnold at the Texas Archeological Research Laboratory at The University of Texas at Austin. 


\section{References Cited}

Fields, R. C.

2019 Spatial Variation in Ripley Engraved Bowls Among the Titus Phase Caddo of Northeast Texas and Communities of Identity. In Ancestral Caddo Ceramic Traditions, edited by D. P. McKinnon, J. S. Girard, and T. K. Perttula. Louisiana State University Press, Baton Rouge, in press.

Perttula, T. K.

2014 Archaeological Studies of the Hatchel Site (41BW3) on the Red River in Bowie County, Texas. Special Publication No. 23. Friends of Northeast Texas Archaeology, Austin and Pittsburg.

2015 Caddo Ceramic Vessels from the Hatchel Site (41BW3) on the Red River in Bowie County, Texas. Special Publication No. 39. Friends of Northeast Texas Archaeology, Austin and Pittsburg.

2018 Analysis of the Hatchel Site (41BW3) Platform Mound Ceramic Vessels, Vessel Sections, Sherds, Pipes, and Other Clay Artifacts. Special Publication No. 45. Friends of Northeast Texas Archaeology, Austin and Pittsburg.

2019 East Texas Caddo Ceramic Traditions. In Ancestral Caddo Ceramic Traditions, edited by D. P. McKinnon, J. S. Girard, and T. K. Perttula. Louisiana State University Press, Baton Rouge, in press.

Regnier, A. L., T. K. Perttula, and P. C. Livingood

2019 Red River Basin in Southeast Oklahoma and Northeast Texas. In Ancestral Caddo Ceramic Traditions, edited by D. P. McKinnon, J. S. Girard, and T. K. Perttula. Louisiana State University Press, Baton Rouge, in press.

Schambach, F. F. and J. E. Miller

1984 A Description and Analysis of the Ceramics. In Cedar Grove: An Interdisciplinary Investigation of a Late Caddo Farmstead in the Red River Valley, edited by N. L. Trubowitz, pp. 109-170. Research Series No. 23. Arkansas Archeological Survey, Fayetteville.

Suhm, D. A. and E. B. Jelks (editors)

1962 Handbook of Texas Archeology: Type Descriptions. Special Publication No. 1, Texas Archeological Society, and Bulletin No. 4, Texas Memorial Museum, Austin. Reprinted in 2009, Gustav's Library, Davenport, Iowa. 